SHS Web of Conferences 2, 00040 (2012)

DOI: $10.1051 /$ shsconf $/ 20120200040$

(C) Owned by the authors, published by EDP Sciences, 2012

\title{
Criminal law policy of Latvia in the context of European Union: The treaty of Lisbon
}

\author{
A. Vilks \\ Rīga Stradiņš University, Latvia
}

\begin{abstract}
The article is devoted to the analysis of the content of EU Treaty of Lisbon, which deals with ensurance of freedom, security and justice in the joint European space. The Treaty of Lisbon describes the attempts of the European Union to ensure a high security level to prevent and fight crime, rasism and xenophobia, to develop particular measures of coordination and cooperation between police and judicial authorities and other competent authorities for their further development, as well as for the mutual recognition of judgements in criminal matters. Correspondingly, the implementation of the requirements of the Treaty of Lisbon identifies the need to form an adequate national criminal law policy in our country as well.
\end{abstract}

Key words: areas of freedom, security, justice, criminal law policy, border control, asylum and legal policy, cooperation of legal authorities

Since May 1, 2004 Latvia is a full-fledged Member State of the European Union. The above-mentioned means that Latvia is bound by legal acts which are accepted and adopted by this international organization. On December 13, 2007 the Treaty of Lisbon was signed. Writing and adopting of the treaty deals with the transformation processes in political, economical and social areas and the wish to justify the expectations of the Europeans of the new regulations which will adjust EU areas of activity and its methods. The Treaty of Lisbon adapts the European institutions and their methods of activities to the current conditions, as well as it is addressing the strengthening of the Union's democratic legitimacy and its fundamental values. (Europe in the 21st century. http://europa.eu/lisbon treaty/take/index_lv.htm).

Joing the ratification of EU treaty, as well as signing of the Treaty of Lisbon determines that Latvia is developing its legal, as well as criminal law policy too, in conformity with the basic guidelines of the European Union, which point to the basic principles and conditions for crime prevention and combating. To a certain extent Latvia's criminal law policy results from common EU legal provisions.

Without negotiating on the issues as to Latvia's legal sovereignty and independence in problem solution, which deals with crime combating, it would still be worth mentioning, that the influence of EU institutions in the formation of criminal law policy in Latvia has to be estimated as really positive.

EU regulations and the directives determined the necessity to introduce changes in the national legal acts, to establish new legal enforcement authorities, which are extremely necessary for the democratic society, to improve crime prevention and combating practice in correspondence with the best European standards, to use more advanced crime prevention technologies, etc. The above-mentioned can be demonstrated by specific examples.

It is essential to recognize the currently existing basic principles and statements of the Treaty of Lisbon which are in force and refer to criminal law policy, and which would have to be considered when drawing a corresponding Latvian strategy and respective programme documents.

Correspondingly to the Treaty of Lisbon chapter 1.A. "The Union is founded considering the values that respect an individual's dignity, freedom, democracy, equality and human rights, minority rights including. These are the common values for the societies of the Member States where govern puralism,

This is an Open Access article distributed under the terms of the Creative Commons Attribution License 2.0, which permits unrestricted use, distribution, and reproduction in any medium, provided the original work is properly cited. 


\section{SHS Web of Conferences}

tolerance, justice, solidarity, where is no discrimination, and where exists the gender equality". As a result, when developing a criminal law policy, it has to be based on human's rights and freedom, and social justice.

An essential criminal law policy aspect is included in the Treaty of Lisbon chapter 2.A., article 2, which says that "the Union offers areas of freedom, security and justice without internal borders, where free movement of persons is ensured in relation to specific activities, referring to the external borders control, asylum seekers, immigration and crime prevention and combating". The Lisbon Treaty precisely states that within the European Union, there is, in fact, a joint legal area; people's protection from unlawful threats is provided by adequate and resultative measures provided by specific law enforcement authorities. In the aspect of criminal law policy Latvia has to work out and provide a set of measures, ensuring an effective EU external border security.

Latvia is fully responsible for prevention and combating of possible criminal threat which might come from EU Eastern border (illegal migrations, smuggling, human trafficking, narcotic crimes, influence of organized criminal groups, etc.). It is worth mentioning that in the current crisis conditions the possibility of criminal type threats, especially the threat to the national security is increasing. It means that problems of security, and in the context of the Treaty of Lisbon, have to be paid a special attention to.

At the same time, Paragraph 3.A. in the Treaty of Lisbon says that "the Union respects the equality of the Member States in relation to the Treaties, as well as the national identity, which is characteristic for their political and constitutional fundamental structures, including regional and local governments. It respects the main functions of the countries, providing each nation's territorial integrity, maintenance of law and order and protection of the country' security. The national security remains the responsibility of each Member State itself" (part 2). We can conclude that for Latvia as the EU Member State, the function is entrusted to ensure the security of EU external borders, to establish and implement the respective criminal law and security policy and strategy, though at the same time, the state possesses sovereign functions to ensure lawfullness, protection of the national security, as well as crime combating. The above-mentioned, seemingly dualistic approach, means that Latvia is entitled to form the national criminal law policy as long as it is not being regulated, not related to or not being in conflict with EU fundamental guidelines and common law provisions.

The more precisely defined principal political statement is included in Chapter 1-General provisions on the Union's external action in article 10.A. which records that the Union sets and implements the common policy and activities (part 2), as well as tends to achieve a high level of cooperation in all fields of international relations, in order:

a) to protect its values, basic interests, security, independence and integrity;

b) to consolidate and support democracy, justice, human rights and principles of international law;

c) to preserve peace, prevent conflicts and strengthen the international security which is in line with the aims and principles of the Statutes of the United Nations Organization, the Helsinki Final Act principles and Paris Charter aims, including those of external borders.

In the Treaty of Lisbon a special chapter 4 is established "AREAS OF FREEDOM, SECURITY AND JUSTICE" which replaces the former chapter IV on visa policy, asylum policy, immigration policy and other policies, which deal with people's free movement. In this chapter there are sections which deal with general provisions, depict the border policy, asylum and immigration policies, consider the cooperation of judicial authorities in civil and criminal matters, as well as deal with the cooperation with the police.

In general provisions of chapter 4, it is strictly defined that the Union provides areas for freedom, security and justice, on account of fundamental rights and different legal systems and traditions of the Member States (61 p.,1.p). Criminal law policy is developed considering the national specificities in legal systems and legal traditions of the countries. 


\section{Int. Conf. SOCIETY. HEALTH. WELFARE; Congr. of Rehabilitation Doctors of Latvia}

It ensures the absence of internal border controls for persons and frames a common policy based on solidarity of the Member States on common asylum, immigration and external borders control towards third-country nationals. For this purpose, stateless persons shall be treated as third-country nationals.

In the context of criminal law policy the Treaty of Lisbon (61 p.3.p) has stated that the Union is trying to provide a high security level of measures in preventing and combating crimes, rasism and xenophobia, and to develop the cooperation between the police and judicial authorities, and other competent authorities, as well as mutual recognition of judgements in criminal matters and, in case of need, the approximation of criminal laws.

National criminal law policy must be open, flexible and with a tendency to wide international cooperation.

The Treaty of Lisbon contributes to the Union's promotion of the availability of judicial institutions, especially when applying the principle of mutual recognition of judicial decisions and extrajudicial decisions in civil matters, as well as in criminal matters.

At the time when the national criminal law policy is being developed, it is essential that the European Council sets the fundamental guidelines in legislation and operational planning strategy in the areas of freedom, security and justice (61.A.p).

In order the fundamental guidelines were successfully developed and would provide a joint strategic planning and cooperation, the Treaty of Lisbon, article 61.D., envisages, that the Council establishes a standing committee in order promotion of operational cooperation and strengthening of internal security issues were provided in the Union. It promotes the coordination of activities of competent authorities of the Member States. Representatives of the Union's respective structures can get involved in the work of this committee. The European Parliament and the national Parliaments receive reports about this work. Consequently, LR Saeima should know what activities of cooperation in the field of crime prevention are worked out and implemented in the EU single legal space.

The article 61.F. of the Treaty of Lisbon envisages that the Member States have a possibility to choose themselves the mutual cooperation and coordination forms, which they consider being appropriate for the cooperation between the competent national regulatory authorities, which are responsible for national security and crime combating.

The Council envisages the measures only to ensure the administrative cooperation between the corresponding structural units of the Member States in those fields which are responsible for security and crime combating between these structural units and the Commission as well.

In relation to unlawful financial operations, transnational crime, fight of terrorism, etc., the European Parliament and the Council, adopting the regulations in line with the common legislative procedure, envisages a system of administrative measures for capital movement and payments, for example, freezing of funds and economic gains or financial assets belonging to natural or legal persons, group or non-state entities.

Chapter 2, section 4 is devoted to the border checks, asylum and immigration policy. We have to admit that Latvia has paid a special attention to the awareness of the problem (Politikas zingojums par migrācijas un patvēruma situāciju Latvijā 2009. gadā. www.emnlatvia.lv).

1. Article 62 of the Treaty of Lisbon states, that the Union makes the policy to:

a) ensure the absence of any controls of persons, whatever their nationality, when crossing the internal borders;

b) carry out checks on persons and provide efficient monitoring of external borders;

c) gradually introduce an integrated management system for external borders.

2. It is doubtless, that the measures mentioned contribute to provision of the EU external border security. To achieve the above-mentioned aims, the European Parliament and the Council, in accordance with the ordinary legislative procedure, envisage the activities on:

a) the common policy of visas and other short-stay residence permits; 


\section{SHS Web of Conferences}

b) checks to which persons crossing the external borders are subject;

c) the conditions under which the third-country nationals have the freedom to travel within the territory of the European Union for a short period;

d) any measures necessary for gradual introduction of an integrated management system for external borders

e) absence of any controls of persons, whatever their nationality, when crossing internal borders.

However, it could be mentioned, that contrary to the requirements of the Treaty of Lisbon, in some cases controls of persons on internal borders are still being done.

3. The Treaty of Lisbon envisages that the Council, in accordance with the ordinary legislative procedure, may adopt provisions concerning passports, ID cards, residence permits or any other such documents.

Section 4, chapter 3 of the Treaty of Lisbon regulates judicial institution cooperation in civil matters.

Seemingly, the cooperation of judicial institutions in the mentioned field does not refer to criminal law policy, yet some of its aspects, which are connected with the property of criminal structures, financial obligations, etc., might be connected with criminal policy.

Article 65 of the Treaty of Lisbon states that the Union develops judicial cooperation in civil matters, having cross-border implications, based on the principle of mutual recognition of judgements and decisions of extrajudicial cases. Such cooperation may include the measures for the approximation of the laws and regulations of the Member States.

The European Parliament and the Council can act in order to ensure:

a) mutual recognition and enforcement between the Member States of judgements and of decisions in extrajudicial cases;

b) the cross-border service of judicial and extrajudicial documents;

c) the compatibility of rules applicable in the Member States concerning the conflict of laws and jurisdiction;

d) cooperation in the taking of evidence;

e) effective access to justice;

f) the elimination of obstacles to the proper functioning of civil proceedings, in case of need by promoting the compatibility of the rules on civil procedure applicable in the Member States;

g) the development of alternative methods of dispute settlement;

h) support for the training of judiciary and judicial staff.

\section{Judicial cooperation in criminal matters}

Article 66 is replaced by article 61G., as set out in point 64, and articles 67-69 are repealed. Chapter 4 and articles $69 \mathrm{a}$ to $69 \mathrm{e}$ are inserted. Article $69 \mathrm{a}, 69 \mathrm{~b}$ and $69 \mathrm{~d}$ replace the current article 31 of the Treaty on the European Union, as set out in the Treaty's article 31, point 51:

The Treaty of Lisbon paragraph 4 , chapter 4 is devoted to the judicial cooperation in criminal matters (5).

Article 69.A. of the Treaty envisages that in the Union the judicial cooperation in criminal matters is based on the principle of mutual recognition of judgments and judicial decisions and includes the approximation of the laws and regulations of the Member States.

The European Parliament and the Council envisage the measures, in order to:

a) lay down rules and procedures for ensuring recognition throughout the Union of all forms of judgments and judicial decisions; 


\section{Int. Conf. SOCIETY. HEALTH. WELFARE; Congr. of Rehabilitation Doctors of Latvia}

b) prevent and settle conflicts of jurisdiction between the Member States;

c) support the training of judiciary and judicial staff;

d) facilitate the cooperation between judicial institutions or equivalent authorities of the Member States in relation to proceedings in criminal matters and the enforcement of decisions.

The European Parliament and the Council can establish minimum rules, in case it is necessary to facilitate mutual recognition of judicial decisions and judgments, as well as cooperation between the police and judicial authorities in criminal matters having a cross-border dimension, by means of directives adopted in accordance with the ordinary legislative procedure. Such rules take into account the differences between the legal traditions and legal systems of the Members States.

These rules concern:

a) mutual admissibility of evidence between the Member States;

b) the rights of individuals in criminal procedure;

c) the rights of victims of crime;

d) any other specific aspects of criminal procedure which the Council has identified in advance by a decision. Having obtained consent of the European Parliament, the Council acts unanimously.

The Treaty of Lisbon also says that the adoption of minimum rules mentioned does not prevent the Member States to maintain or introduce a higher protection level for individuals.

The Treaty of Lisbon contains also an article (69.A.3p) saying that, if some draft directive might influence a single country's fundamental aspects of the criminal law system, then one can demand its suspension in the European Council.

It is essential that the Treaty of Lisbon, article 69.A., includes conditions, saying that the European Parliament and the Council, when adopting directives, can establish the minimum rules concerning the definition of criminal offences and sanctions in the areas of particularly serious crime with a cross-border dimension, resulting from the nature or impact of such offences, or from a special need to combat them on a common basis.

Priorities of the European Union when defining the amount of minimum sanctions refer to the following crimes like: terrorism, human trafficking, sexual exploitation of women and children, illicit drug trafficking, illicit arms trafficking, money laundering, corruption, counterfeiting of means of payments, computer crime and organized crime.

Besides, considering developments of crime, the Council may adopt a decision, identifying other areas of crime, that meet the criteria specified above.

In the development of criminal law policies, the Treaty of Lisbon, article 69.C., envisages that the European Parliament and the Council can establish measures to promote and support the action of the Member States in the field of crime prevention, excluding any harmonisation of the laws and regulations of the Member States.

The mission of such EU institution as Eurojust is to support and strengthen the coordination and cooperation between national investigating and prosecuting authorities in relation to serious crime, affecting at least two Member States, or requiring a prosecution on common bases, on the basis of operations conducted and information supplied by the authorities of the Member States and by Europol.

In this context, the European Parliament and the Council, when adopting the rules, determine Eurojust's structure, operation, field of action and tasks. They could be:

a) to initiate criminal investigations, as well as criminal prosecution, conducted by competent national authorities, particularly those relating to offences against financial interests of the Union;

b) to coordinate the action of specific investigation;

c) to strengthen judicial cooperation, including resolution of conflicts of jurisdiction and closely cooperate with the European Judicial Network. 


\section{SHS Web of Conferences}

EC regulations can also determine the arrangements, how the European Parliament and national Parliaments (6) are involved in the evaluation of Eurojust's activities.

Article 69.E. of the Treaty of Lisbon envisages also the implementation of individual measures which concern special interests of EU.

Thus, in order to combat crimes affecting the financial interest of the Union, the Council, by means of regulations, may establish a European Public Prosecutor from Eurojust. Having obtained the consent of the European Parliament, the Council can take a corresponding decision.

The European Public Prosecutor's Office is responsible for investigating, prosecuting and bringing to judgment, where appropriate in liason with Europol, the peretrators and accomplices in offences against the Union's financial interests, are identified. It exercises the functions of prosecutor in the competent courts of the Member States in relation to such offences.

Accepting the regulation, which is applicable to the European Public Prosecutor, there are included conditions, the rules of procedure, admissibility of evidence of the activities, and the rules applicable to the judicial review of procedural measures, taken by it in the performance of its functions.

The establishment of criminal law policy and its realization in crime combating is inconceivable without participation of the police.

Paragraph 4, chapter 5 of the Treaty of Lisbon states the cooperation of the police.

Thus, article 69.F. of the Treaty envisages that the Union is developing the cooperation with the police, involving all the competent institutions of the Member States including police, customs and other specialized law enforcement services of the Member States which specialize in prevention, detection and investigation of criminal offences.

The European Parliament and the Council, acting in accordance with the ordinary legislative procedure, may establish measures concerning:

a) the collection, storage, analysis and exchange of relevant information;

b) support for the training of staff and cooperation on the exchange of staff, on equipment and on research into crime-detection;

c) common investigative techniques in relation to the detection of serious forms of organised crime.

The Council may establish measures concerning operational cooperation between the authorities mentioned.

One of the most important authorities providing the cooperation of police authorities Europol.

According to the article 69.G. of the Treaty of Lisbon, the Europol's mission is to support and strengthen action and mutual cooperation of the police authorities and other law enforcement services on preventing and combating serious crime affecting at least two Member States, as well as terrorism and forms of crime which affect a common interest covered by a Union policy.

The European Parliament and the Council determine Europol's structure, operation, field of action and tasks. These tasks are as follows:

a) to collect, store, process, analyze the information and exchange the information forwarded by the authorities of the Member States or third countries or bodies;

b) to coordinate, organize and implement the investigative and operational action carried out jointly with the competent authorities of the Member States or joint investigative teams, where appropriate in liason with Eurojust.

Any operational action by Europol must be carried in liason and in agreement with the Member States or States whose territory is concerned. The application of coercive measures depends exclusively on the responsibility of competent national authorities. 
Int. Conf. SOCIETY. HEALTH. WELFARE; Congr. of Rehabilitation Doctors of Latvia

\section{Conclusions}

The Treaty of Lisbon, in general, is an essential instrument in improvement of joint EU legal policy, providing free movement and security of the European Union citizens. Cooperation of the police, state border guards, immigration service, Procurator's Office and judicial authorities is established and implemented on the basis of common provisions. Implementation of the Treaty of Lisbon in the aspect of the establishment and implementation of the criminal law policy is significant for Latvia, which is a young EU Member State, whose economic and financial crisis is particularly severe.

\section{References}

[1] Europe in the 21st century. http://europa.eu/lisbon_treaty/take/index_lv.htm

[2] Eiropas Savienības oficiālais vēstnesis. http://eurlex.europa.eu/JOHtml.do? uri= OJ :C: $2007: 306:$ SOM :LV :HTML

[3] Jundzis, T. (2009) National Security Challenges Arsing from the Global Economic Crisis. The Fifth Year as European Union Member States: Topical Problems in Management of Economics and Law. Proceedings of the International Conference 8-9 May, 2009. Riga.

[4] Politikas ziņojums par migrācijas un patvēruma situāciju Latvijā 2009. gadā. Rīga, 2009. gada decembris. www.emnlatvia.lv (emn.intrasoft-intl.com/Downloads/download.do; jsessionid...? fileID...)

[5] Tiesu sadarbība civillietās un krimināllietās. http://circa.europa.eu/irc/opoce/fact_ sheets/info/data/policies/freedom/article_7309_lv.htm

[6] Rules of Procedure of Eurojust. http://www. eurojust.europa.eu/ 